\title{
FRUIT QUALITY AND RESISTANCE OF STRAWBERRY CULTIVARS AND HYBRIDS AND THE EFFECT OF CALCITE FERTILISER
}

\author{
Valda Laugale", Sandra Dane, Līga Lepse, and Sarmìte Strautina \\ Institute of Horticulture, Latvia University of Agriculture, Graudu iela 1, Cerinii, Krimūnu pag., Dobeles nov., LATVIA \\ \# Corresponding author, valda.laugale@llu.lv
}

Communicated by Edite Kaufmane

\begin{abstract}
Strawberry (Fragaria $\mathrm{x}$ ananassa Duchense ex Rozier) is an important horticultural crop grown in Latvia. The aim of this research was to evaluate some newly introduced strawberry cultivars and

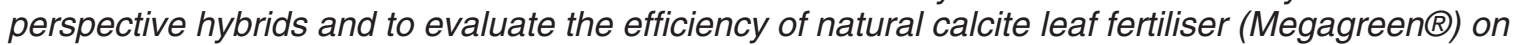
strawberry fruit quality and spread of pests and diseases. The trial was established in 2012 at Pūre, Tukums Municipality. Cultivars 'Saint Pierre', 'Annapolis', 'Sonata', 'Chambly', 'Elegance', 'Rumba', 'Honeoye', 'Senga Sengana' and two hybrids: 35-1 and 39-1 were included in the investigation. Calcite fertiliser was applied four times per season in 2013 and 2014 by spraying on leaves in concentration $0.5 \%$. Strawberries were grown on two row beds with black plastic mulch and drip irrigation. The evaluation was done for two seasons. Most of the evaluated newly introduced cultivars and hybrids had better fruit quality and resistance to diseases than control cultivars. Cultivars 'Annapolis', 'Rumba', 'Sonata', 'Elegance', and 39-1 were selected as the most

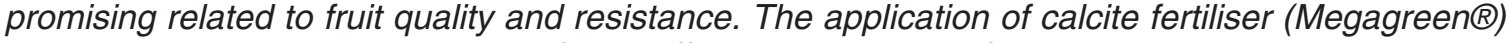
on leaves had no statistically significant effect on strawberry fruit quality and resistance.
\end{abstract}

Key words: Fragaria $x$ ananassa Duchense ex Rozier, harvesting season, winter hardiness, fruit size, pest and disease resistance.

\section{INTRODUCTION}

Strawberry (Fragaria $x$ ananassa Duchense ex Rozier) is one of the most popular commercial berry crops in Latvia. They are mainly grown under open field conditions, and the production is used for fresh consumption and sold in local markets. Fruit quality of old cultivars is not in line with today's market demands, and growers are looking for new, better cultivars. Winter hardiness and resistance to diseases and pests are also important due to the climatic conditions in Latvia and decreased number of registered plant protection products.

Proper plant nutrition is very important for good plant health, high productivity and fruit quality (Lanauskas et al., 2006). Ca is known as an important mineral nutrient for plants, which acts in the stabilisation of the cell wall, metabolism, and formation of cell nucleus, it acts as a secondary messenger in metabolic regulations, and promotes uptake of nitrate $\mathrm{N}$ and some cations, i.e. $\mathrm{K}$ (Clarkson and Hanson, 1980). The positive effect of calcium fertilisers on strawberry firmness, rot resistance, and storage quality is known (Cheour et al., 1990., 1991; Wójcik and Lewandowski, 2003). However, a positive effect of calcium has not been observed in all cases (Makus and Morris, 1994; Erincik et al., 1998; Lanauskas et al., 2006).

The aim of this study was to evaluate ten strawberry cultivars and hybrids and the effect of natural calcium fertiliser foliar application.

\section{MATERIALS AND METHODS}

The experiment was carried out at the Pūre Horticultural Research Centre, Latvia $\left(57^{\circ} 02^{`} \mathrm{~N}\right.$ and $\left.22^{\circ} 52^{`} \mathrm{E}\right)$. The experimental site was situated on loam soil on dolomite bedrock, $\mathrm{pH}_{\mathrm{KCl}} 7.4, \mathrm{~K}-235 \mathrm{mg} \cdot \mathrm{L}^{-1} ; \mathrm{P}-316 \mathrm{mg} \cdot \mathrm{L}^{-1} ; \mathrm{Mg}-$ $8150 \mathrm{mg} \cdot \mathrm{L}^{-1} ; \mathrm{Ca}-15050 \mathrm{mg} \cdot \mathrm{L}^{-1}$.

Cultivars 'Saint Pierre', 'Annapolis', 'Sonata', 'Chambly', 'Elegance', 'Rumba', and hybrids 35-1 and 39-1 produced from local breeding were included in the investigation. 'Honeoye' (early ripening) and 'Senga Sengana' (medium late ripening) were used as controls. Locally grown fresh dug bare root plants were planted in the middle of June, 2012 in 0.8-m-wide two row beds mulched with black plastic. A complex fertiliser $\left(\mathrm{N}-\mathrm{P}_{2} \mathrm{O}_{5}-\mathrm{K}_{2} 0: 15-8-18+\right.$ microelements) with dose $30 \mathrm{~g}$ per bed meter was applied during 
preparation of beds. The distance between plants in rows and between rows on beds was $0.3 \mathrm{~m}$. The distance between bed centres was $1.5 \mathrm{~m}$. Drip irrigation and fertigation was applied in the trial. The irrigation and fertigation was done one to two times per week from May 30 to August 26 in 2013 and from June 10 to September 2 in 2014. In total, 245 $\mathrm{L}$ of water, $6.5 \mathrm{~g}$ of $\mathrm{N}, 0.4 \mathrm{~g}$ of $\mathrm{P}_{2} \mathrm{O}_{5}$, and $14.0 \mathrm{~g}$ of $\mathrm{K}_{2} \mathrm{O}$ were applied per bed metre in 2013 and $158 \mathrm{~L}$ of water, 1.9 $\mathrm{g}$ of $\mathrm{N}, 1.2 \mathrm{~g}$ of $\mathrm{P}_{2} \mathrm{O}_{5}$ and $14.5 \mathrm{~g}$ of $\mathrm{K}_{2} \mathrm{O}$ were applied per bed meter in 2014. Additionally, at the beginning of new leaf growth, ammonium nitrate in concentration $1 \%$ was sprayed. Mowing of weeds and herbicide Basta ${ }^{\mathrm{TM}}$ (200 $\mathrm{g} \cdot \mathrm{L}^{-1}$ glufosinate-ammonium) with dose $6 \mathrm{~L} \cdot \mathrm{ha}^{-1}$ were used between beds. No fungicides were used for disease control. To prevent spread of pests and diseases, all leaves and runners were cut and removed from the field after end of fruit harvest. The acaricide Danadim ${ }^{\mathrm{TM}}$ (400 g. $\mathrm{L}^{-1}$ dimethoate) was used for mite control with dose $1.2 \mathrm{~L} \cdot \mathrm{ha}^{-1}$ after end of fruit harvest in 2013. The insecticide Fastac $50^{\mathrm{TM}}$ (alphacypermethrin $50 \mathrm{~g} \mathrm{~L}^{-1}$ ) was applied with dose $0.4 \mathrm{~L} \cdot \mathrm{ha}^{-1}$ before strawberry flowering in 2014 .

Cultivars and hybrids were planted in randomly located plots in four replicates with 30 plants per plot. A natural leaf fertiliser Megagreen ${ }^{\circledR}\left(\mathrm{CaCO}_{3}-95 \%, \mathrm{SiO}_{2}-2 \%\right.$, $\mathrm{MgO}-1.5 \%, \mathrm{Fe}-8783 \mathrm{mg} \cdot \mathrm{kg}^{-1}, \mathrm{Mn}-156 \mathrm{mg} \cdot \mathrm{kg}^{-1}, \mathrm{Se}-$ $0.24 \mathrm{mg} \cdot \mathrm{kg}^{-1}$ ) was applied for half of the plots four times per season by spraying on leaves in concentration $0.5 \%$ $\left(500 \mathrm{~L} \cdot \mathrm{ha}^{-1}\right)$. In 2013, the spraying was done on 28 May, 6 June, 14 August, and 30 August. In 2014, the spraying was done on 29 April, 13 May, 30 May, and 2 September.

The evaluations were performed for two growing seasons: 2013 and 2014. Strawberry flowering and fruit ripening time was recorded. Winter damage, total yield, amount of grey mould damaged fruits (in \% from total), average fruit weight, and susceptibility to disease and pests were recorded during the both seasons. Winter damage was evaluated visually at the beginning of the vegetation season using a scale 1-9 (where $1=$ no visual winter injury; $3=$ up to $15 \%$ of leaves and crowns damaged, $10 \%$ of plants dead; $5=$ up to $50 \%$ of leaves and crowns damaged, $25 \%$ of plants dead; 7 = up to $75 \%$ of leaves and crowns damaged, $50 \%$ of plants dead; $9=$ all plants totally injured/dead). Strawberry blossom weevil (Anthonomus rubi) damage was recorded as percentage of damaged flower buds on 10 plants per plot. The susceptibility to leaf diseases - the common leaf spot (Mycosphaerella fragariae Tul., Lindau.) and leaf scorch (Diplocarpon earlianum Ellis \& Everh) and strawberry mite (Tarsonemus pallidus) was evaluated visually after end of fruit harvest using a scale 1-9 (where $1=$ no visual damages, and $9=$ totally injured all plants). Sensory evaluation of fruits was performed. The sensory panel consisted of 10-12 trained persons who scored the fruit taste and appearance on a scale of 1-9, where $1=$ unacceptable, 3 = weak, $5=$ medium, $7=$ good, $9=$ excellent. The amount of soluble solids $\left(\mathrm{Brix}^{\mathrm{o}}\right)$ was determined using a hand refractometer, and fruit firmness (g) using a Wagner fruit penetrometer (cap size $6 \mathrm{~mm} \varnothing$ ) pressing it till $8 \mathrm{~mm}$ depth, at maximum fruit harvest for five ripe fruits from every plot.

Descriptive statistics, analysis of variance, followed by a LSD test $(p \leq 0.05)$ and Pearson's correlation were used for data analysis. Data were analysed using the Dell ${ }^{\mathrm{TM}}$ Statistica $^{\text {TM }}$ software. Duncan's multiple range test was applied to compare means (probability 95\%).

\section{RESULTS}

Flowering and fruit ripening time. In the trial, the earliest maximum peak flowering time was observed for 'Annapolis', 35-1, 'Rumba' and Chambly' (Table 1). The earliest beginning of fruit harvest was observed for the same cultivars, which was similar to that of control cultivar 'Honeoye'. Only hybrid 39-1 had a later ripening time than the control cultivar 'Senga Sengana'. It was characterised also by the latest flowering time. Other cultivars had medium ripening time. The peak flowering time significantly positively correlated with fruit ripening time $(\mathrm{r}=0.62 ; \mathrm{n}=$ 80). 'Annapolis' had the shortest harvest period, whereas the longest harvest period was observed for 'Rumba'. The application of Megagreen fertiliser did not significantly affect strawberry flowering and harvest seasons. However, there were some differences among cultivars. 'Elegance' had a significantly later time of beginning of fruit ripening in the treatment with application of Megagreen fertiliser,

Table 1

STRAWBERRY FLOWERING AND FRUIT HARVEST TIME FOR CULTIVARS AND EFFECTS OF FERTILISER TREATMENTS, AVERAGE OF TWO YEARS

\begin{tabular}{|c|c|c|c|c|c|}
\hline \multirow{2}{*}{$\begin{array}{l}\text { Cultivar, } \\
\text { treatment }\end{array}$} & \multirow{2}{*}{$\begin{array}{c}\text { Maximum of } \\
\text { flowering, day } \\
\text { of the year }\end{array}$} & \multicolumn{4}{|c|}{ Fruit harvesting } \\
\hline & & \multicolumn{2}{|c|}{$\begin{array}{c}\text { beginning, } \\
\text { day of the } \\
\text { year }\end{array}$} & $\begin{array}{l}\text { end, day of } \\
\text { the year }\end{array}$ & $\begin{array}{c}\text { duration, } \\
\text { days }\end{array}$ \\
\hline \multicolumn{6}{|l|}{ Cultivar } \\
\hline Honeoye & $146.3 \quad a b^{1}$ & 162.0 & $\mathrm{a}$ & 190.8 & 28.8 \\
\hline Senga Sengana & $147.6 \mathrm{bcd}$ & 165.0 & $\mathrm{c}$ & 199.0 & 34.0 \\
\hline Saint Pierre & $147.9 \mathrm{~cd}$ & 165.0 & $\mathrm{c}$ & 198.5 & 33.5 \\
\hline Annapolis & 145.1 & 161.3 & $\mathrm{a}$ & 184.4 & 23.1 \\
\hline $39-1$ & 148.8 & 167.1 & $\mathrm{~d}$ & 198.4 & 31.3 \\
\hline $35-1$ & 145.3 & 161.5 & $\mathrm{a}$ & 189.8 & 28.3 \\
\hline Sonata & $147.6 \mathrm{bcd}$ & 163.5 & $\mathrm{bc}$ & 197.5 & 34.0 \\
\hline Chambly & 146.0 & 162.5 & $a b$ & 192.8 bc & 30.3 \\
\hline Elegance & $146.4 \mathrm{abc}$ & 164.3 & $\mathrm{c}$ & 197.3 & 33.0 \\
\hline Rumba & 145.4 & 161.8 & $\mathrm{a}$ & $196.1 \mathrm{~cd}$ & 34.4 \\
\hline$p$ value & $<0.01$ & \multicolumn{2}{|c|}{$<0.01$} & $<0.01$ & $<0.01$ \\
\hline \multicolumn{6}{|l|}{ Treatment } \\
\hline With Megagreen & 146.7 & \multicolumn{2}{|l|}{163.6} & 194.2 & 30.7 \\
\hline $\begin{array}{l}\text { Without } \\
\text { Megagreen }\end{array}$ & 146.6 & \multicolumn{2}{|l|}{163.2} & 194.7 & 31.5 \\
\hline$p$ value & 0.627 & \multicolumn{2}{|c|}{0.293} & 0.585 & 0.374 \\
\hline
\end{tabular}

${ }^{1}$ Values in a column followed by the same letter do not differ significantly by Duncan's multiple range test $(p=0.05)$ 
Table 2

STRAWBERRY FRUIT SIZE, CONTENT OF SOLUBLE SOLIDS AND FIRMNESS FOR CULTIVARS AND EFFECTS OF FERTILISER TREATMENTS

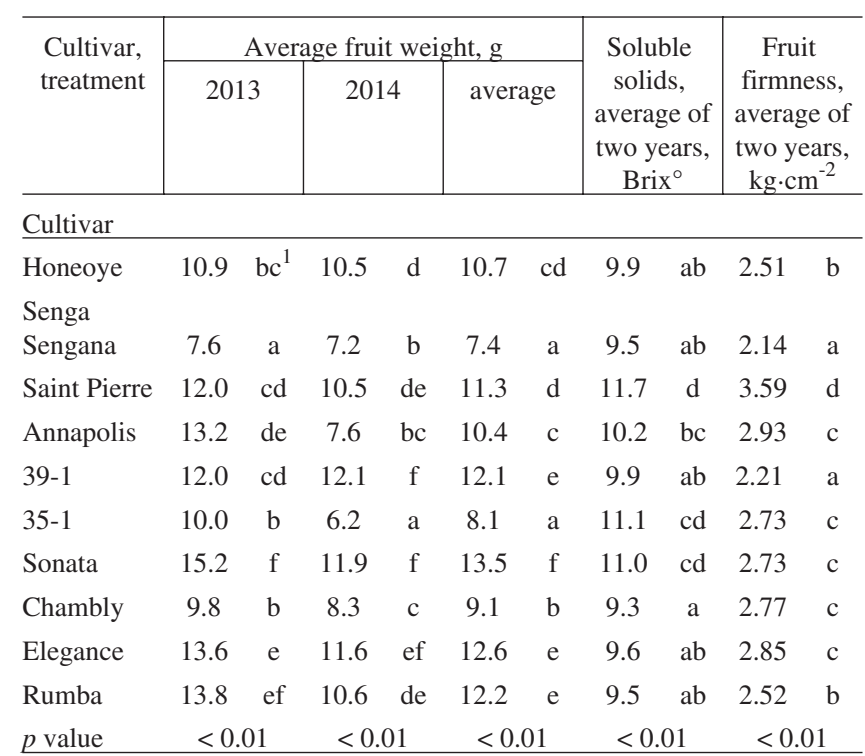

\section{Treatment}

With

$\begin{array}{lccccc}\text { Megareen } & 11.7 & 9.7 & 10.7 & 10.1 & 2.72 \\ \text { Without } & & & & & \\ \text { Megagreen } & 11.9 & 9.6 & 10.8 & 10.2 & 2.67 \\ p \text { value } & 0.515 & 0.773 & 0.682 & 0.546 & 0.261\end{array}$

${ }^{1}$ Values in a column followed by the same letter do not differ significantly by Duncan`s multiple range test $(p=0.05)$

compare to untreated, while 'Rumba' had earlier time of end of fruit harvest and shorter harvest season.

Fruit quality. Fruit size was larger in 2013 than in 2014 for most cultivars and hybrids (Table 2). All of the evaluated cultivars and hybrids had larger fruits than the control cultivar 'Senga Sengana', while 'Sonata', 'Elegance' and 'Rumba' had the largest. They also obtained the highest score for fruit appearance (Fig. 1). 'Saint Pierre', 35-1 and 'Sonata' had the highest soluble solids content, which was significantly higher than for both controls. The highest fruit firmness was observed for 'Saint Pierre', whereas 'Senga Sengana' had the softest fruits. During the fruit sensory evaluation, 'Sonata' received the highest score for fruit taste, and 39-1 had the lowest score.

In general, the application of Megagreen calcium fertiliser did not significantly affect strawberry fruit size and quality, but some increase of fruit firmness was observed. A significant increase $(p<0.01)$ of fruit firmness was observed only for 'Rumba' $\left(+0.38 \mathrm{~kg} \cdot \mathrm{cm}^{-2}\right.$ or $\left.16 \%\right)$ compared to the untreated control. However, the application of Megagreen fertiliser significantly $(p<0.01)$ reduced the average fruit size for 'Rumba' $(-1.5 \mathrm{~g}$ or $11 \%)$.

Winter damage and spreading of pests and diseases. During the two evaluation years, 'Senga Sengana' and

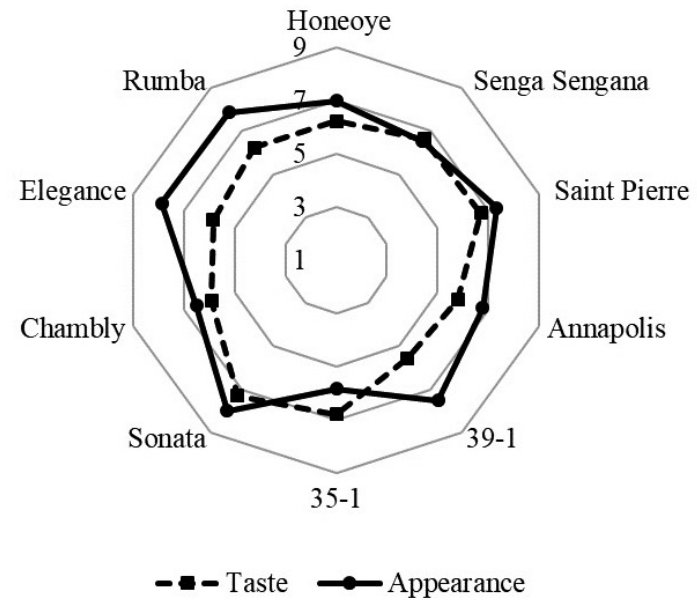

Fig. 1. Strawberry fruit sensory evaluation for taste and appearance, scores $1-9$, average of two years.

'Saint Pierre' had the lowest winter damage while 35-1 was the most damaged (Table 3). Other cultivars and hybrid 39-1 had similar winter hardiness to the control cultivar 'Honeoye'.

Leaf diseases and grey mold were observed in the trial. Leaf scorch was more spread than common leaf spot disease. 'Senga Sengana' had the lowest amount of damage by leaf scorch, and 35-1 was the most damaged. All evaluated cultivars and hybrids had better resistance to the common leaf spot disease than 'Senga Sengana'. No symptoms were observed on 'Saint Pierre', 'Annapolis' and 'Chambly'. The amount of grey mold damaged fruits was low in both evaluation years. In general for the two years of study, the highest disease damage was observed for control cultivar 'Senga Sengana', while 'Annapolis' was the most resistant.

Serious strawberry blossom weevil and strawberry mite damage was observed during the trial. During the two years, 'Honeoye' and 'Annapolis' had the lowest damage, while 'Saint Pierre' suffered the most damage. The lowest amount of damage by strawberry mite was observed for 'Chambly', 'Rumba' and 39-1, while the highest amount was recorded for 'Sonata'.

In general, no statistically significant effect of application of Megagreen fertiliser on the occurrence of pests and diseases was observed.

\section{DISCUSSION}

Significant difference between evaluated cultivars and hybrids regarding flowering and fruit ripening time, fruit quality and resistance to pests and diseases was observed. The evaluated cultivars and hybrids can be divided in three groups according to fruit ripening time: early ripening 'Annapolis', 35-1, 'Rumba', 'Honeoye' and 'Chambly'; medium ripening time — 'Sonata', 'Elegance', 'Saint Pierre' and 'Senga Sengana'; late ripening — 39-1. Growers are usually more interested in early and late ripening cultivars to prolong the strawberry production season and to 
WINTER DAMAGE AND DAMAGE BY PESTS AND DISEASES FOR STRAWBERRY CULTIVARS AND EFFECTS OF FERTILISER TREATMENTS, AVERAGE OF TWO YEARS

\begin{tabular}{|c|c|c|c|c|c|c|c|c|c|c|c|c|}
\hline Cultivar, treatment & \multicolumn{2}{|c|}{ Winter damage* } & \multicolumn{2}{|c|}{ Common leaf spots* } & \multicolumn{2}{|c|}{ Leaf scorch* } & \multicolumn{2}{|c|}{$\begin{array}{l}\text { Grey mold damaged } \\
\text { fruits, } \% \text { from total }\end{array}$} & \multicolumn{2}{|c|}{$\begin{array}{c}\text { Strawberry blossom } \\
\text { weevil damaged } \\
\text { buds, \% from total }\end{array}$} & \multicolumn{2}{|c|}{ Strawberry mite* } \\
\hline \multicolumn{13}{|l|}{ Cultivar } \\
\hline Honeoye & 5.0 & $\operatorname{cde}^{1}$ & 1.9 & $\mathrm{ab}$ & 4.5 & $\mathrm{~d}$ & 0.88 & $\mathrm{ab}$ & 13.9 & a & 3.8 & $\mathrm{c}$ \\
\hline Senga Sengana & 3.1 & $\mathrm{a}$ & 4.8 & $\mathrm{~d}$ & 1.4 & $\mathrm{a}$ & 3.23 & $\mathrm{c}$ & 15.2 & $\mathrm{ab}$ & 4.3 & $\mathrm{~cd}$ \\
\hline Saint Pierre & 3.9 & $\mathrm{~b}$ & 1.0 & $\mathrm{a}$ & 3.5 & bc & 1.78 & $\mathrm{~b}$ & 28.1 & $\mathrm{c}$ & 3.9 & $\mathrm{~cd}$ \\
\hline $39-1$ & 4.5 & $\mathrm{bc}$ & 2.3 & $\mathrm{bc}$ & 3.6 & $\mathrm{bc}$ & 2.11 & $\mathrm{bc}$ & 19.8 & $\mathrm{abc}$ & 2.8 & $\mathrm{~b}$ \\
\hline $35-1$ & 6.4 & $\mathrm{f}$ & 1.5 & $\mathrm{ab}$ & 5.8 & $\mathrm{e}$ & 1.08 & $\mathrm{ab}$ & 18.4 & $\mathrm{ab}$ & 4.5 & cde \\
\hline Sonata & 5.0 & cde & 1.5 & $\mathrm{ab}$ & 3.6 & $\mathrm{bc}$ & 1.69 & $\mathrm{~b}$ & 22.2 & $\mathrm{abc}$ & 5.5 & $\mathrm{e}$ \\
\hline Chambly & 4.5 & $\mathrm{bc}$ & 1.0 & a & 4.1 & $\mathrm{~cd}$ & 0.27 & $\mathrm{a}$ & 18.0 & $\mathrm{ab}$ & 1.5 & $\mathrm{a}$ \\
\hline Elegance & 4.8 & $\mathrm{~cd}$ & 1.1 & $\mathrm{ab}$ & 3.5 & $\mathrm{bc}$ & 1.54 & $\mathrm{~b}$ & 16.6 & $\mathrm{ab}$ & 3.9 & $\mathrm{~cd}$ \\
\hline Rumba & 5.6 & $\mathrm{e}$ & 3.1 & $\mathrm{bc}$ & 3.0 & $\mathrm{~b}$ & 0.16 & $\mathrm{a}$ & 23.7 & $\mathrm{bc}$ & 2.5 & $\mathrm{~b}$ \\
\hline \multicolumn{13}{|l|}{ Treatment } \\
\hline With Megareen & \multicolumn{2}{|c|}{4.9} & \multicolumn{2}{|c|}{2.0} & \multicolumn{2}{|c|}{3.7} & \multicolumn{2}{|c|}{1.36} & \multicolumn{2}{|c|}{17.2} & \multicolumn{2}{|c|}{3.6} \\
\hline Without Megagreen & \multicolumn{2}{|c|}{4.8} & \multicolumn{2}{|c|}{1.8} & \multicolumn{2}{|c|}{3.6} & \multicolumn{2}{|c|}{1.20} & \multicolumn{2}{|c|}{20.7} & \multicolumn{2}{|c|}{3.9} \\
\hline $\mathrm{p}$ value & \multicolumn{2}{|c|}{0.544} & \multicolumn{2}{|c|}{0.326} & \multicolumn{2}{|c|}{0.430} & \multicolumn{2}{|c|}{0.128} & \multicolumn{2}{|c|}{0.053} & \multicolumn{2}{|c|}{0.114} \\
\hline
\end{tabular}

obtain higher fruit price by selling out of season. In our trial, 'Annapolis' and 'Rumba' were the most promising among early ripening cultivars. 'Annapolis' had similar fruit size to the early ripening control cultivar 'Honeoye', as well as good resistance to diseases. Good resistance of 'Annapolis' to leaf spot disease was also reported by Delhomez et al (1995). 'Rumba' had larger and more attractive fruits, and better resistance to strawberry mite than 'Honeoye'. However, it had more damage by common leaf spot and strawberry blossom weevil. Hybrid 39-1 had the latest fruit ripening time among evaluated cultivars and hybrids. It had large, attractive fruits, but of medium taste and firmness, and it had good resistance to strawberry mite. 'Sonata' and 'Elegance' showed the best results among medium ripening cultivars. Both of them had large, firm and attractive fruits, while winter hardiness was lower, as for 'Senga Sengana'. 'Sonata' also had low resistance to pests, especially to strawberry mite. Good fruit taste and susceptibility to strawberry mite of 'Sonata' was reported also by Pfeifer and Brockamp (2010). Good fruit quality of 'Elegance' was reported by Simpson et al. (2014). More investigations on these cultivars and hybrids are necessary in different growing regions of Latvia.

Foliar sprays of calcium are recommended for strawberry due to demand for calcium during peak production for rapidly growing strawberry fruits (Anonymous, 2000). In contrast, Makus and Morris (1998) reported that foliar applied $\mathrm{Ca}$ did not affect fruit $\mathrm{Ca}$ concentrations. In our trial, foliar application of natural calcite fertiliser (Megagreen $®$ ) had no statistically significant effect on strawberry. This can be explained by high concentration of calcium in the soil, which probably was sufficiently available for plants. According to Norton and Wittwer (1963), Ca uptake occurs mainly through the root system in strawberry plants. However, some cultivars showed response to foliar application of calcium fertiliser in the trial, which might be explained by different requirements for calcium among cultivars. Different $\mathrm{Ca}$ concentrations in fruits among cultivars have been reported previously (Albregts and Howard, 1978; Makus and Morris, 1998).

The application of calcium fertiliser influenced the duration of the harvesting period for cultivar 'Rumba' and beginning of fruit harvesting for 'Elegance' in our trial. An effect of foliar application of calcium to delay ripening has been reported from Poland (Wójcik and Lewandowski, 2003). There are contradictory results reported on the increase of fruit firmness after application of calcium fertiliser. A positive effect was reported by $\mathrm{Na}$ Phun et al. (1995) and Wójcik and Lewandowski (2003), whereas a negative effect was reported by Makus and Morris (1994) and Ericik et al. (1998). In our trial, calcium fertilisation increased fruit firmness only for 'Rumba'. Probably this occurred due to the decrease of fruit size for this cultivar. It is reported that small fruits are firmer than large ones (Døving and Måge, 2002). The application of calcium fertiliser did not increase the content of soluble solids in fruits, which is consistent with observations of Makus and Morris (1987, 1989) and Lanauskas et al. (2006) Fertiliser treatment also did not reduce pest and disease damage. As the results are not convincing, more investigations in less calcareous soils are necessary to determine the effectiveness of Megagreen fertiliser. 


\section{ACKNOWLEDGEMENTS}

This work was supported by the Latvia Ministry of Agriculture Project "The evaluation of small fruit cultivars perspective for integrated production in different regions of Latvia and developing and improvement of growing technologies".

\section{REFERENCES}

Albregts, E. E., Howard C. M. (1978). Elemental composition of fresh strawberry fruit. J. Amer. Soc. Hort. Sci., 102, 293-296.

Anonymous (2000). Calcium in fruit production. A\&L Canada Laboratories Small Fruit News Letter, 5. Available at: http://www.alcanada.com/index_htm_files/berry_patch-v05.pdf (accessed 3 June 2017).

Cheour, F., Willemot, C., Arul, J., Makhlouf, J., Charest, P. M., Gosselin, A. (1990). Foliar application of calcium chloride delays postharvest ripening of strawberry. J. Amer. Soc. Hort. Sci., 115, 789-792.

Cheour, F., Willemot, C., Arul, J., Makhlouf, J., Desjardins, Y. (1991). Postharvest response of two strawberry cultivars to foliar application of $\mathrm{CaCl}_{2}$. HortScience, 26 (9), 1186-1188.

Clarkson, D. T., Hanson J. B. (1980). The mineral nutrition of higher plants. Annu. Rev. Plant Physiol., 31, 239-298.

Delhomez, N., Carisse, O., Lareau, M., Khanizadeh, S. (1995). Susceptibility of strawberry cultivars and advanced selections to leaf spot caused by Mycosphaerella fragariae. HortScience, 30 (3), 592-595.

Døving, A., Måge, F. (2002). Testing strawberry fruit firmness. Acta Agric. Scand., Sect B, Soil and Plant Sci., 52, 43-51.
Erincik, O., Madden, L. V., Scheerens, J. C., Ellis, M. A. (1998). Evaluation of foliar application of calcium chloride for control of Botrytis fruit rot on strawberry and effects on strawberry fruit quality. Adv. Strawberry Res., 17, 7-13.

Lanauskas, J., Uselis, N., Valiuškaite, A., Viškelis, P. (2006). Effect of foliar and soil applied fertilisers on strawberry healthiness, yield and berry quality. Agron. Res., 4, 247-250.

Makus, D. J., Morris J. R. (1987). Effect of supplemental calcium on postharvest strawberry fruit quality. Proc. Arkansas State Hort. Soc., 108, $52-57$.

Makus, D. J., Morris J. R. (1994). Effect of preharvest calcium applications on firmness, decay and mineral distribution in strawberry fruit. HortScience, 29, 533.

Na Phun, W., Kawada, K., Kusunoki M. (1995). Effect of preharvest calcium application on postharvest quality of 'Nyoho' strawberries. J. Japan Soc. Hort. Sci., 2, 638-639.

Norton, R. A., Wittwer, S. H. (1963). Foliar and root absorption and distribution of phosphorus and calcium in the strawberry. Proc. Amer. Soc. Hort. Sci., 82, 277-286.

Pfeifer, B., Brockamp, L. (2010). Which strawberry-varieties are suitable for organic fruit growers. In: Proceedings of XIV International Conference on Organic Fruit Growing, Universität Hohenheim, Germany, February, 22, pp. 371-375.

Simpson, D. W., Whitehouse, A. B., Johnson, A. W., McLeary, K. J., Passey, A. J. (2014). 'Elegance' and 'Vibrant', two new strawberry cultivars for programmed cropping in Northern Europe. Acta Hort., 1049, 259-261.

Wójcik, P., Lewandowski, M. (2003). Effect of calcium and boron sprays on yield and quality of 'Elsanta' strawberry. J. Plant Nutr., 26 (3), 671-682.

\section{ZEMEN̦U ŠK়IRN̦U UN HIBRĪDU OGU KVALITĀTES UN IZTURĪBAS IZVĒRTĒJUMS UN KALCIJA MĒSLOJUMA IETEKME}

Zemenes (Fragaria x ananassa Duchense ex Rozier) ieņem nozīmīgu vietu starp audzētajiem aug̣̦augiem Latvijā. Pētījuma mērķis bija izvērtēt jaunintroducētās zemeṇu škirnes un perspektīvos hibrīdus un dabiskā kalcija lapu mēslojuma (Megagreen®) ietekmi uz zemenu ogu kvalitāti un slimību un kaitēkḷu izplatību. Izmēgeinājums tika rīkots 2012. gadā Pūrē, Tukuma novadā. Pētījumā vērtētas šḳirnes: 'Saint Pierre', 'Annapolis', 'Sonata', 'Chambly', 'Elegance', 'Rumba', 'Honeoye', 'Senga Sengana', un hibrīdi: 35-1 un 39-1. Kalcija mēslojums tika dots 2013. un 2014. gadā četras reizes sezonā, smidzinot to uz lapām 0,5\% koncentrācijā. Zemenes tika audzētas divrindu dobēs ar melnās plēves mulču un pilienveida apūdeņošanu. Vērtēšana tika veikta divas sezonas. Lielākajai daḷai vērtēto jaunintroducēto škirņu un hibrīdu bija raksturīga labāka ogu kvalitāte un izturība pret slimībām nekā kontrolšḳirnēm. Škiirnes 'Annapolis', 'Rumba', 'Sonata', 'Elegance' un hibrīds 39-1 tika izdalīti kā vislabākie attiecībā uz ogu kvalitāti un izturību. Organiskā kalcija mēslojuma (Megagreenß) lietošana, smidzinot to uz lapām, statistiski būtiski neietekmēja zemeṇu ogu kvalitāti un izturību pret kaitēkliem un slimībām. 